Article

\title{
Preparation of a fullerene[60]-iron oxide complex for the photo-fenton degradation of organic contaminants under visible-light irradiation
}

\author{
Cong-yang Zou a,b, Ze-da Meng b, Wen-chao Ji a,,Shou-qing Liu b, Zhemin Shen ${ }^{\text {a,* }}$, Yuan Zhang ${ }^{\text {b }}$ \\ $\mathrm{Ni}$-shan Jiang ${ }^{b}$ \\ a School of Environmental Science and Engineering, Shanghai Jiao Tong University, Shanghai 200240, China \\ ${ }^{\mathrm{b}}$ School of Environmental Science and Engineering, Suzhou University of Science and Technology Shihu Campus, Suzhou 215009, Jiangsu, China
}

\section{A R T I C L E I N F O}

\section{Article history:}

Received 8 January 2018

Accepted 21 March 2018

Published 5 June 2018

\section{Keywords:}

$\mathrm{C}_{60}-\mathrm{Fe}_{2} \mathrm{O}_{3}$

Heterogeneous photocatalysis

Photo-Fenton

Visible light

Active species trapping

\begin{abstract}
A B S T R A C T
Iron oxide $\left(\mathrm{Fe}_{2} \mathrm{O}_{3}\right)$ was doped onto fullerene[60] $\left(\mathrm{C}_{60}\right)$ to form a $\mathrm{C}_{60}-\mathrm{Fe}_{2} \mathrm{O}_{3}$ composite using an easy and scalable impregnation method. The as-prepared $\mathrm{C}_{60}-\mathrm{Fe}_{2} \mathrm{O}_{3}$ samples were characterized by powder X-ray diffraction, X-ray photoelectron spectroscopy, scanning electron microscopy, high-resolution transmission electron microscopy, UV-vis absorption spectroscopy, Raman spectroscopy, and Fourier transform infrared spectroscopy. The photocatalytic activity of the $\mathrm{C}_{60}-\mathrm{Fe}_{2} \mathrm{O}_{3}$ catalyst was evaluated by examining the degradation of methylene blue (MB), rhodamine B (RhB), methyl orange (MO), and phenol under visible light $(\lambda>420 \mathrm{~nm})$ in the presence of hydrogen peroxide. The results showed that the catalyst exhibited excellent catalytic properties over a wide $\mathrm{pH}$ range 3.06-10.34. Under optimal conditions, $98.9 \%$ discoloration and $71 \%$ mineralization of $\mathrm{MB}$ were achieved in $80 \mathrm{~min}$. Leaching test results indicated that the leaching of iron from the catalyst was negligible and that the catalyst had a high photocatalytic activity after five reaction cycles. The catalyst was also efficient in the degradation of RhB, MO, and phenol. These findings could be attributed to the synergetic effects of $\mathrm{C}_{60}$ and $\mathrm{Fe}_{2} \mathrm{O}_{3}$. We used active species trapping experiments to determine the main active oxidant in the photocatalytic reaction process and found that hydroxyl radicals played a major role in the entire process.
\end{abstract}

(C) 2018, Dalian Institute of Chemical Physics, Chinese Academy of Sciences. Published by Elsevier B.V. All rights reserved.

\section{Introduction}

With rapid industrial development over the past few decades, large volumes of colored dye effluents have created severe environmental pollution problems by releasing toxic and potentially carcinogenic substances into the aqueous phase $[1,2]$. Waste accumulation has a serious adverse impact on the environment and is dangerous to human health [3]. Advanced oxidation processes (AOPs) have emerged as promising alternative processes for wastewater treatment, especially for persistent and nonbiodegradable contaminants, such as dyeing wastewater [4-6]. As one of the most important AOPs, photo-Fenton degradation of organic dyes using hydrogen peroxide $\left(\mathrm{H}_{2} \mathrm{O}_{2}\right)$ /visible light has been widely studied [7-9]. In this

\footnotetext{
*Corresponding author. Tel: +86-21-54745262; Fax: +86-21-54742863; E-mail: shenzhemin@sina.com.cn

The work was supported by the National Natural Science Foundation of China $(21347006,21576175,51478285,51403148)$, the Opening Project of Key Laboratory of Jiangsu Province environmental science and engineering of Suzhou University of Science and Technology (zd131205), Collaborative Innovation Center of Technology and Material of Water Treatment and Suzhou Key Lab of Separation and Purification Materials \& Technologies (SZS201512).

DOI: 10.1016/S1872-2067(18)63067-0 | http://www.sciencedirect.com/science/journal/18722067 | Chin. J. Catal., Vol. 39, No. 6, June 2018
} 
process, the photodegradation efficiency depends on the decomposition rate of $\mathrm{H}_{2} \mathrm{O}_{2}$. Therefore, developing a photocatalyst to enhance the visible-light-driven activity is important.

Fullerene[60] $\left(\mathrm{C}_{60}\right)$, which has a unique three-dimensional structure because of its delocalized $\pi$ electrons, has gained considerable attention; the delocalized conjugated structures of $\mathrm{C}_{60}$ molecules allow weak absorption in the visible range and high electron mobility $\left(>1.3 \mathrm{~cm}^{2} / \mathrm{V} / \mathrm{s}\right)[10,11]$. Hence, $\mathrm{C}_{60}$ can be photochemically activated under visible-light irradiation, resulting in rapid photoinduced charge separation with a high quantum efficiency and relatively slow charge recombination [12-14]. Some recent studies have focused on investigating the utilization of visible light for the treatment of pollutants by coupling $\mathrm{C}_{60}$ with other semiconductors with low band gaps [15-18].

Iron oxide $\left(\mathrm{Fe}_{2} \mathrm{O}_{3}\right)$ is an abundant, stable, cost-effective, nontoxic, and environmentally benign n-type semiconductor with a band gap of $2.2 \mathrm{eV}$ [19]. Owing to its unique and fascinating physicochemical properties, several researchers have investigated the behavior of $\mathrm{Fe}_{2} \mathrm{O}_{3}$ in diverse fields such as water splitting [20], catalysis [21], and medicine [22]. Recently, $\mathrm{Fe}_{2} \mathrm{O}_{3}$ has been used to form hybrid materials with carbon nanomaterials, such as multiwall carbon nanotubes, graphene oxide, and graphene, for the degradation of organic pollutants under visible-light irradiation [23-25]. However, the application of a heterogeneous $\mathrm{C}_{60}-\mathrm{Fe}_{2} \mathrm{O}_{3}$ catalyst for the photo-Fenton degradation of organic contaminants has not been reported to date.

In this study, $\mathrm{C}_{60}-\mathrm{Fe}_{2} \mathrm{O}_{3}$ composites were prepared for the first time via an easy and scalable impregnation method at 60 ${ }^{\circ} \mathrm{C}$. The photocatalytic activity of $\mathrm{C}_{60}-\mathrm{Fe}_{2} \mathrm{O}_{3}$ was evaluated by examining the degradation of methylene blue (MB), rhodamine $\mathrm{B}(\mathrm{RhB})$, and methyl orange (MO) in the presence of $\mathrm{H}_{2} \mathrm{O}_{2}$ under visible light. The effects of operating parameters, such as initial $\mathrm{pH}$, catalyst dosage, and $\mathrm{H}_{2} \mathrm{O}_{2}$ dosage, were investigated. A possible mechanism for photo-Fenton degradation was also discussed.

\section{Experimental}

\subsection{Materials}

Crystalline fullerene powder (99.9\% purity) was purchased from Suzhou Dade Carbon Nanotechnology Co., Ltd. $m$-Chloroperoxybenzoic acid (MCPBA), $\mathrm{H}_{2} \mathrm{O}_{2}(30 \%, \mathrm{~W} / \mathrm{W})$, ferric chloride hexahydrate $\left(\mathrm{FeCl}_{3} \cdot 6 \mathrm{H}_{2} \mathrm{O}\right)$, sulfuric acid $(98 \%)$, sodium hydroxide, and benzene $(99.5 \%)$ were purchased from Tianjin Damao Chemical Factory. MB, RhB, and MO were used as model dye pollutants without further purification. All the experiments were conducted using deionized (DI) water.

\subsection{Oxidation of fullerene}

For the oxidization of $\mathrm{C}_{60}$, MCPBA was used as the oxidizing agent. MCPBA (ca. $1 \mathrm{~g}$ ) was suspended in $50 \mathrm{~mL}$ of benzene, followed by the addition of fullerene (ca. $80 \mathrm{mg}$ ). The mixture was heated under reflux in air and stirred for $6 \mathrm{~h}$ in a $250 \mathrm{~mL}$ distillation flask. The solvent was then removed at the boiling point of benzene $\left(80^{\circ} \mathrm{C}\right)$. After completion, the dark-brown precipitate was washed with ethyl alcohol and dried at $50{ }^{\circ} \mathrm{C}$ to obtain oxidized fullerene.

\subsection{Preparation of $\mathrm{C}_{60}-\mathrm{Fe}_{2} \mathrm{O}_{3}$}

Oxidized $\mathrm{C}_{60}$ (ca. $1 \mathrm{~g}$ ) was added to $100 \mathrm{~mL}$ of water and ultrasonically exfoliated in a bath sonicator for $15 \mathrm{~min}$. Then, 20 $\mathrm{mL}$ of $0.2 \mathrm{~mol} / \mathrm{L} \mathrm{FeCl}_{3}$ solution was added slowly into the aqueous solution of functionalized $\mathrm{C}_{60}$ and stirred for $2 \mathrm{~h}$ at 60 ${ }^{\circ} \mathrm{C}$ in a $250 \mathrm{~mL}$ distillation flask. After the obtained suspension was aged for at least $8 \mathrm{~h}$ at $60{ }^{\circ} \mathrm{C}$, the obtained solids were collected and washed five times with DI water. After drying under vacuum at $60{ }^{\circ} \mathrm{C}$ for $8 \mathrm{~h}$, a chemically bonded $\mathrm{C}_{60}-\mathrm{Fe}_{2} \mathrm{O}_{3}$ composite was finally obtained.

\subsection{Characterization}

X-ray diffraction (XRD) analysis on a D8 Advance diffractometer (Bruker, Germany) was performed to identify the structure and crystallinity of the as-prepared samples with monochromatic high-intensity $\mathrm{Cu} K_{\alpha}$ radiation $(\lambda=1.5406 \AA)$. High-resolution transmission electron microscopy (HR-TEM) (Tecnai G220, USA) and scanning electron microscopy (SEM, JEOL, Japan) were conducted to analyze the morphology and microstructure of the prepared composites at an acceleration voltage of $200 \mathrm{kV}$. Fourier transform infrared (FT-IR) spectroscopy (Nicolet 6700; Thermo Ltd., Japan) was carried out to detect the chemical bonds on the surface of the catalyst. The mulls of $\mathrm{C}_{60}-\mathrm{Fe}_{2} \mathrm{O}_{3}$ were supported by a $\mathrm{KBr}$ plate. UV-vis diffuse reflectance spectra were obtained using a UV-vis spectrophotometer (UV-3600, Shimadzu Ltd., Japan). Photoluminescence measurements were conducted on a fluorescence spectrophotometer (RF-5300PC, Shimadzu, Japan) at room temperature. X-ray photoelectron spectroscopy (XPS; XSAM 800) was employed to characterize the iron states. The binding energies were calibrated with respect to the $\mathrm{C} 1 s$ peak at $284.6 \mathrm{eV}$. Peak deconvolution was performed using Gaussian-Lorentzian components after linear background subtraction.

\subsection{Photo-Fenton degradation tests and analytical methods}

The photocatalytic activity of the $\mathrm{C}_{60}-\mathrm{Fe}_{2} \mathrm{O}_{3}$ catalyst was evaluated by examining the degradation of $\mathrm{MB}, \mathrm{MO}$, and $\mathrm{RhB}$ under visible-light irradiation $(\lambda>400 \mathrm{~nm})$. A $300 \mathrm{~W}$ UV-vis lamp (OSRAM, Germany) was used as a light source. The photo-Fenton degradation of organic compounds was performed in a $100 \mathrm{~mL}$ beaker at room temperature $\left(25 \pm 2{ }^{\circ} \mathrm{C}\right)$. The reaction beaker was located axially and held in a visible lamp box. The lamp was located at a distance of approximately $100 \mathrm{~mm}$ from the aqueous solution in a dark box. The wall of the beaker was shielded from surrounding light with tinfoil. Visible light was obtained with a $\lambda>400 \mathrm{~nm}$ cut-off filter, which covered the window of the beaker to absorb UV light and allow visible light of $\lambda>400 \mathrm{~nm}$ to pass through. Around $50 \mathrm{~mL}$ of test solution was typically used in the photo-Fenton experiments. The initial 
concentration of the dyes was set at $50 \mathrm{mg} / \mathrm{L}$ in all experiments. The amount of photocatalytic composite used was 0.02 $\mathrm{g} /\left(50 \mathrm{~mL}\right.$ solution). A $5 \mathrm{mmol} / \mathrm{L} \mathrm{H}_{2} \mathrm{O}_{2}$ aqueous solution (30\%) was added to the reaction solution at the beginning of the irradiation. The reactor was placed on a magnetic churn dasher. The suspension was then irradiated with visible light for a set irradiation time. Visible-light irradiation of the reactor was performed for 20, 40, 60, and $80 \mathrm{~min}$. Samples of approximately $5 \mathrm{~mL}$ were withdrawn regularly from the reactor, and dispersed powders were removed using a centrifuge. The clean transparent solution was analyzed using a UV-vis spectrophotometer (UVmini-1240, Shimadzu, Japan). The content of total organic carbon (TOC) was determined with a multi N/C 3100 TOC analyzer (Analytik Jena AG, Germany). In addition, to investigate the iron leaching behavior from the $\mathrm{C}_{60}-\mathrm{Fe}_{2} \mathrm{O}_{3}$ catalyst, the iron ion concentration in solution versus time was determined by atomic absorption spectroscopy (AAS).

\section{Results and discussion}

\subsection{XRD measurements}

Using XRD, the phase and structure of $\mathrm{C}_{60}$, oxidized $\mathrm{C}_{60}$, and $\mathrm{C}_{60}-\mathrm{Fe}_{2} \mathrm{O}_{3}$ were investigated. As shown in Fig. 1(a) The characteristic diffraction peaks of oxidized $\mathrm{C}_{60}$ appeared at diffraction angles of $2 \theta=10.98^{\circ}, 17.9^{\circ}$, and $20.96^{\circ}$; these diffractions peaks were shifted towards lower angles compared with those of $\mathrm{C}_{60}$ and agreed well with the data reported in the literature $[26,27]$. However, no diffraction peaks corresponding to $\mathrm{Fe}_{2} \mathrm{O}_{3}$ were detected. This result may be ascribed to the small amount of $\mathrm{Fe}_{2} \mathrm{O}_{3}$ introduced (Fe content of $3.25 \mathrm{wt} \%$ ) and the high dispersion of $\mathrm{Fe}_{2} \mathrm{O}_{3}$ on the surface of $\mathrm{C}_{60}$ balls. The diffraction peak of $\mathrm{C}_{60}-\mathrm{Fe}_{2} \mathrm{O}_{3}$ was shifted towards a lower $2 \theta$ angle of $17.68^{\circ}$, corresponding to a $d$-spacing of $5.01 \mathrm{~nm}$. This phenomenon could be attributed to the intercalation of $\mathrm{Fe}_{2} \mathrm{O}_{3}$. No impurity peak was found in the $\mathrm{C}_{60}-\mathrm{Fe}_{2} \mathrm{O}_{3}$ hybrid. The average diameter (D) of the as-synthesized $\mathrm{C}_{60}-\mathrm{Fe}_{2} \mathrm{O}_{3}$ particles was calculated as $27.9 \mathrm{~nm}$ using the Debye-Scherrer equation [28], $D=$ $K k /(W \cos \theta)$, at a diffraction angle of $17.68^{\circ}(2 \theta)$. In this equation, $W$ is the breadth of the observed diffraction peak at its half height, $K$ is the so-called shape factor (usually approximately $0.89)$, and $k$ is the wavelength of the X-ray source used $(0.154$
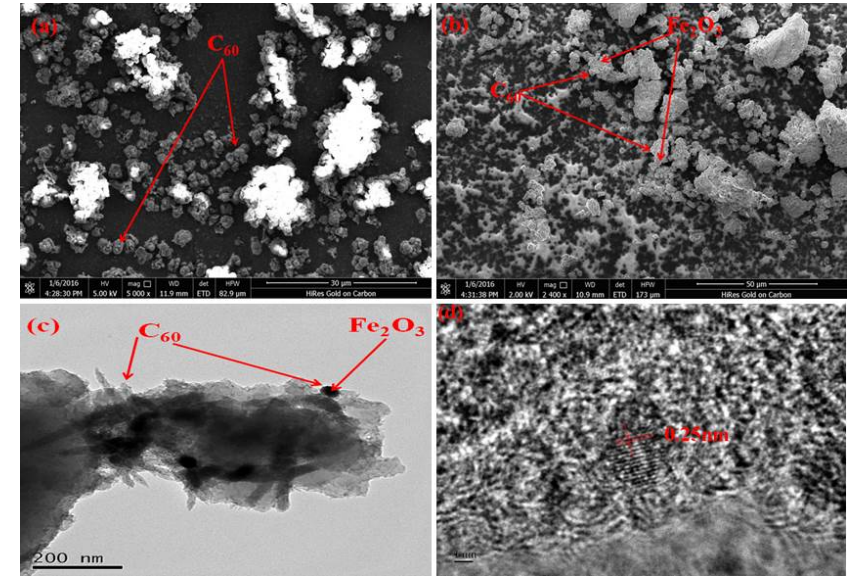

Fig. 2. SEM images of $\mathrm{C}_{60}$ (a) and $\mathrm{C}_{60}-\mathrm{Fe}_{2} \mathrm{O}_{3}$ (b); TEM image (c) and HR-TEM image (d) of $\mathrm{C}_{60}-\mathrm{Fe}_{2} \mathrm{O}_{3}$.

nm in our measurements). The calculated $D$ value based on the Debye-Scherrer equation is very similar to that obtained from TEM observations.

\subsection{XPS analysis}

To further confirm the existence of Fe species and investigate the electronic states of the elements in the catalyst, XPS analysis was performed (Fig. 1(b) and (c)). The XPS spectrum (Fig. 1(b)) shows a composition of C, 0 , and Fe elements, with three sharp peaks appearing at binding energies of 284.8 (C 1s), 532.4 (O 1s), and 710.9 (Fe $2 p$ ) eV. As shown in Fig. 1(c), the binding energies of $\mathrm{Fe} 2 p_{3 / 2}$ and $\mathrm{Fe} 2 p_{1 / 2}$ are located at 710.9 and $724.1 \mathrm{eV}$, respectively; these values are in good agreement with the values of $\mathrm{Fe}_{2} \mathrm{O}_{3}$ reported in previous literature [29]. Furthermore, a shakeup satellite peak is clearly observed at approximately $719.1 \mathrm{eV}$, which is characteristic of $\mathrm{Fe}^{3+}$ species [30].

\subsection{SEM, TEM, and HR-TEM observations}

Representative SEM, TEM, and HR-TEM images of oxidized $\mathrm{C}_{60}$ and the as-obtained $\mathrm{C}_{60}-\mathrm{Fe}_{2} \mathrm{O}_{3}$ catalyst are given in Fig. 2. In Fig. 2(a) and (b), $\mathrm{Fe}_{2} \mathrm{O}_{3}$ has a small particle size and good dispersion and the oxidized fullerene clusters are spherical parti-
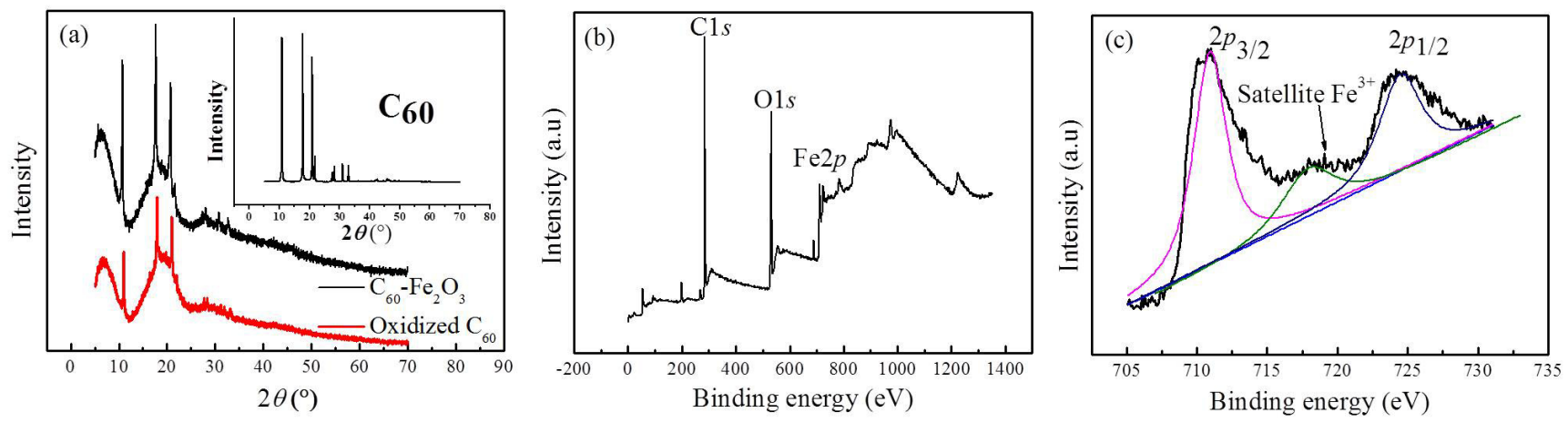

Fig. 1. (a) XRD patterns of oxidized $\mathrm{C}_{60}$ and $\mathrm{C}_{60}-\mathrm{Fe}_{2} \mathrm{O}_{3}$. The inset shows the XRD pattern of $\mathrm{C}_{60}$; (b) XPS full survey spectrum of $\mathrm{C}_{60}-\mathrm{Fe}_{2} \mathrm{O}_{3}$; (c) $\mathrm{XPS} \mathrm{Fe} 2 p$ spectrum of $\mathrm{C}_{60}-\mathrm{Fe}_{2} \mathrm{O}_{3}$. 
cles with small facets and good dispersion. Comparing Fig. 2(a) and (b), we conjecture that the spherical particles in $\mathrm{C}_{60}-\mathrm{Fe}_{2} \mathrm{O}_{3}$ composites are oxidized fullerene clusters. $\mathrm{Fe}_{2} \mathrm{O}_{3}$ structures are visible on the $\mathrm{C}_{60}$ surface, despite the low doping ratio. TEM was used to obtain additional information about the interfacial region of the fullerene composite.

As shown in Fig. 2(c), fullerene particles can be clearly observed and small clusters of irregularly agglomerated $\mathrm{Fe}_{2} \mathrm{O}_{3}$ nanoparticles are distributed on the surface of fullerene. $\mathrm{Fe}_{2} \mathrm{O}_{3}$ nanoparticles with an average particle size of 20-30 nm are dispersed on the spherical fullerene surface. The size data obtained from TEM observations are very similar to the $D$ value calculated from the Debye-Scherrer equation. Further HR-TEM analysis, as shown in Fig. 2(d), revealed a lattice fringe spacing of $0.25 \mathrm{~nm}$, which corresponds to the (110) crystallographic plane of crystalline $\mathrm{Fe}_{2} \mathrm{O}_{3}$.

\subsection{FT-IR characterization}

The chemical structures of oxidized $\mathrm{C}_{60}$ and the $\mathrm{C}_{60}-\mathrm{Fe}_{2} \mathrm{O}_{3}$ catalyst, the oxygen-containing functionalities, and their changes after impregnation were confirmed by FT-IR spectroscopy. Fig. 3(a) shows the FT-IR spectra of oxidized $\mathrm{C}_{60}$, $\mathrm{Fe}_{2} \mathrm{O}_{3}$, and $\mathrm{C}_{60}-\mathrm{Fe}_{2} \mathrm{O}_{3}$. The peaks at 591.81, 1097.44, 1403.5, and $1640 \mathrm{~cm}^{-1}$ are fundamental infrared active modes consistent with those reported in previous literature; these peaks are attributed to the internal modes of the functionalized $\mathrm{C}_{60}$ molecule [31]. The $\mathrm{C}_{60}-\mathrm{Fe}_{2} \mathrm{O}_{3}$ composite also contains these functional groups, and the positions of the peaks are consistent with those of oxidized $\mathrm{C}_{60}$. However, the sharpness of the peaks is different, suggesting some changes in the functional groups of $\mathrm{C}_{60}-\mathrm{Fe}_{2} \mathrm{O}_{3}$. The peak at $1640 \mathrm{~cm}^{-1}$ for oxidized $\mathrm{C}_{60}$ shifts to $1630.53 \mathrm{~cm}^{-1}$ for $\mathrm{C}_{60}-\mathrm{Fe}_{2} \mathrm{O}_{3}$ and the intensity decreases. A small dip also exists in the spectra at $2377 \mathrm{~cm}^{-1}$ because of the presence of atmospheric $\mathrm{CO}_{2}$ [32]. Moreover, the two distinct absorption bands located at 475.76 and $619.27 \mathrm{~cm}^{-1}$ in the photocatalytic samples are attributed to iron-oxygen stretching in $\gamma-\mathrm{Fe}_{2} \mathrm{O}_{3}$. Similar observations have been documented in the literature [33], suggesting that $\mathrm{Fe}_{2} \mathrm{O}_{3}$ is connected to the $-\mathrm{OH}$ groups on the surface of the $\mathrm{C}_{60}$ cages [34]. This is in good agreement with the results of the TEM analysis.

\subsection{UV-vis diffuse reflectance absorption characterization}

Fig. 3(b) shows typical UV-vis diffuse reflectance spectra for $\mathrm{C}_{60}, \mathrm{Fe}_{2} \mathrm{O}_{3}$, and $\mathrm{C}_{60}-\mathrm{Fe}_{2} \mathrm{O}_{3}$ photocatalysts. The absorption spectrum of pure $\mathrm{Fe}_{2} \mathrm{O}_{3}$ showed weak absorption in the visible region (400-650 nm). By contrast, the as-prepared $\mathrm{C}_{60}-\mathrm{Fe}_{2} \mathrm{O}_{3}$ nanocomposite showed strong absorption over the visible region $(>400 \mathrm{~nm})$. These results suggest that the response of the photocatalyst doped with fullerene to visible light was enhanced; this characteristic has been observed in many fullerene composite materials [35]. In this study, the capability of the $\mathrm{C}_{60}-\mathrm{Fe}_{2} \mathrm{O}_{3}$ material to fully utilize visible light was confirmed by the photodegradation of MB.

\subsection{Raman characterization}

Raman spectroscopy was used to characterize the crystal structure of the obtained $\mathrm{C}_{60}-\mathrm{Fe}_{2} \mathrm{O}_{3}$ particles. Fig. 3(c) shows the Raman spectra of fullerene and $\mathrm{C}_{60}-\mathrm{Fe}_{2} \mathrm{O}_{3}$. $\mathrm{C}_{60}$ exhibits strong peaks at 1365 and $1588 \mathrm{~cm}^{-1}$. Both spectra indicate the presence of amorphous carbon structures assigned to the pentagonal pinch mode $[\operatorname{Ag}(2)]$ and the vibrations of carbon atom domains of $\mathrm{C}_{60}$ [36]. Compared with fullerene, the intensity of the $\mathrm{Ag}(2)$ peak for the $\mathrm{C}_{60}-\mathrm{Fe}_{2} \mathrm{O}_{3}$ cage was decreased because of the strong $\pi-\pi$ stacking interactions between $\mathrm{C}_{60}$ molecules and $\mathrm{Fe}_{2} \mathrm{O}_{3}$. These findings confirm that $\mathrm{Fe}_{2} \mathrm{O}_{3}$ is bound to the surface of $\mathrm{C}_{60}$.

\subsection{Photo-Fenton degradation of organic dyes}

Fig. 4(a) shows the discoloration of MB using the as-prepared catalyst under different conditions. In the reaction system with $\mathrm{H}_{2} \mathrm{O}_{2}$ and without the $\mathrm{C}_{60}-\mathrm{Fe}_{2} \mathrm{O}_{3}$ catalyst (test a), very little degradation of MB was found after irradiation for 80 min. However, the degradation of $\mathrm{MB}$ increased significantly with the $\mathrm{C}_{60}-\mathrm{Fe}_{2} \mathrm{O}_{3}$ catalyst added into the reaction system with (test c) and without $\mathrm{H}_{2} \mathrm{O}_{2}$ (test b). Therefore, the $\mathrm{C}_{60}-\mathrm{Fe}_{2} \mathrm{O}_{3}$ composite plays a very important role in the decomposition of MB. As shown in Fig. 4(a)d, nearly $70 \%$ of MB was degraded by the $\mathrm{C}_{60}-\mathrm{Fe}_{2} \mathrm{O}_{3}$ catalyst after irradiation under visible light for 80 min. This result may be attributed to the efficient separation of
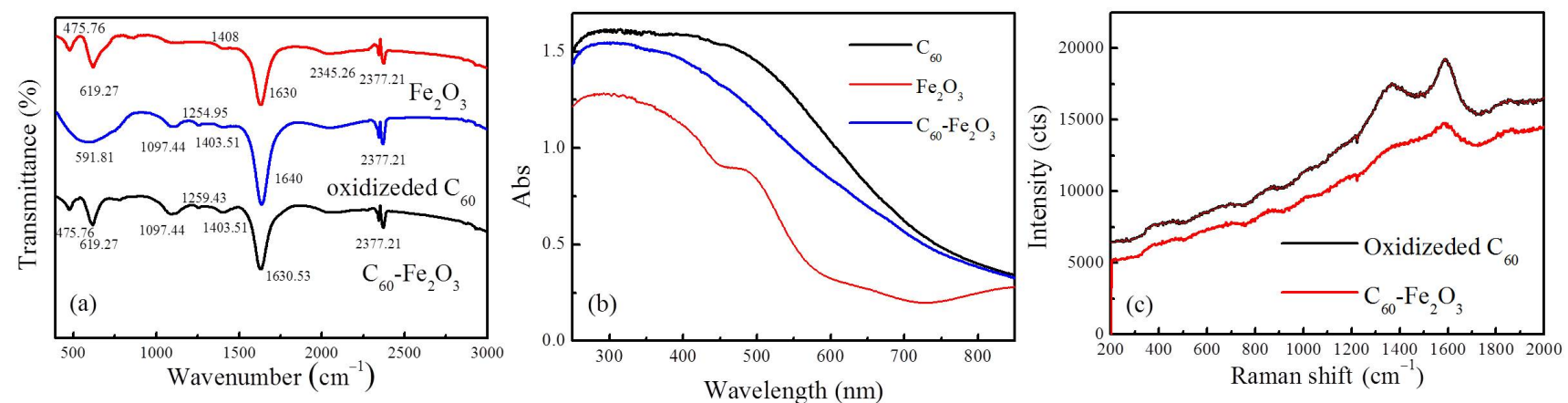

Fig. 3. (a) FT-IR spectra of $\mathrm{Fe}_{2} \mathrm{O}_{3}$, oxidized $\mathrm{C}_{60}$, and $\mathrm{C}_{60}-\mathrm{Fe}_{2} \mathrm{O}_{3}$; (b) UV-vis diffuse reflectance spectra of $\mathrm{C}_{60}$, $\mathrm{Fe}_{2} \mathrm{O}_{3}$, and $\mathrm{C}_{60}-\mathrm{Fe}_{2} \mathrm{O}_{3}$; (c) $\mathrm{Raman}_{6}$ spectra of oxidized $\mathrm{C}_{60}$ and $\mathrm{C}_{60}-\mathrm{Fe}_{2} \mathrm{O}_{3}$. 

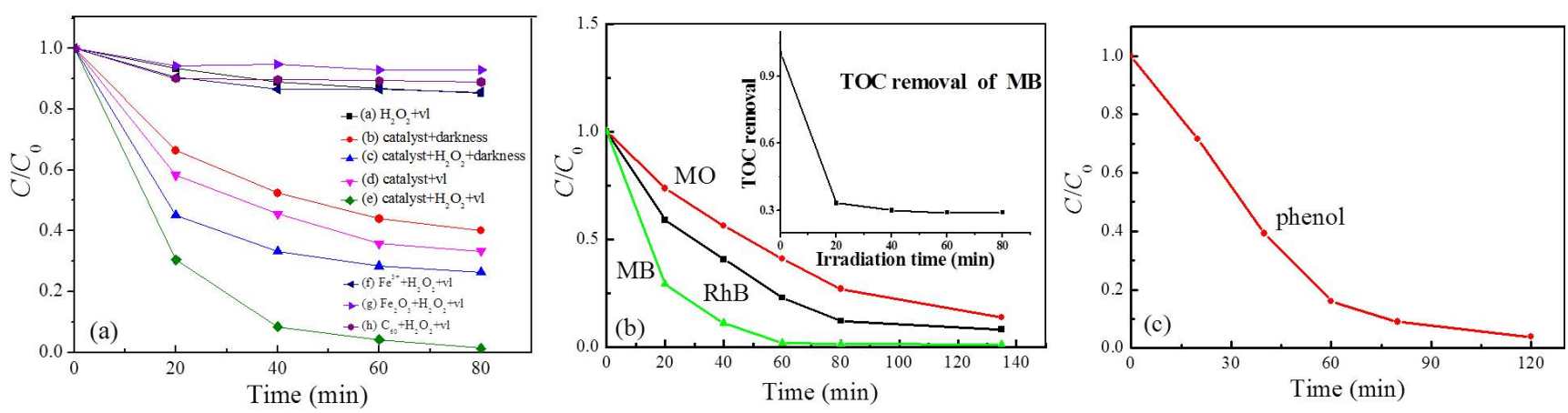

Fig. 4. (a) Photocatalytic degradation of $\mathrm{MB}(50 \mathrm{mg} / \mathrm{L}, 50 \mathrm{~mL})$ using $0.02 \mathrm{~g}$ of catalyst under various conditions; (b) Photocatalytic degradation of RhB MO, or $\mathrm{MB}\left(50 \mathrm{mg} / \mathrm{L}, 50 \mathrm{~mL}\right.$ ) using $0.02 \mathrm{~g} \mathrm{C}_{60}-\mathrm{Fe}_{2} \mathrm{O}_{3}$ and $5 \mathrm{mmol} / \mathrm{L} \mathrm{H}_{2} \mathrm{O}_{2}$ under visible light. The inset shows the TOC removal rate of MB; (c) Degradation of phenol $(10 \mathrm{mg} / \mathrm{L}, 50 \mathrm{~mL})$ under $\mathrm{C}_{60}-\mathrm{Fe}_{2} \mathrm{O}_{3} / \mathrm{H}_{2} \mathrm{O}_{2} /$ visible light conditions.

photogenerated carriers in the coupled $\mathrm{Fe}_{2} \mathrm{O}_{3}$ and $\mathrm{C}_{60}$ system. As shown in Fig. 4(a)b, approximately $67 \%$ of MB was adsorbed in the dark after 80 min. This finding shows that the $\mathrm{C}_{60}-\mathrm{Fe}_{2} \mathrm{O}_{3}$ material has a very high adsorption capacity for MB. The degradation rate of MB was enhanced to $74 \%$ (Fig. 4(a)c) when $\mathrm{H}_{2} \mathrm{O}_{2}$ was added to the reaction solution. However, even in the presence of both $\mathrm{H}_{2} \mathrm{O}_{2}$ and the catalyst, $\mathrm{MB}$ was still not degraded completely in the dark. Meanwhile, nearly $99 \%$ of MB was decomposed by the hybrid composite in the presence of $\mathrm{H}_{2} \mathrm{O}_{2}$ (test e) under visible-light irradiation for $80 \mathrm{~min}$. These results may be ascribed to the remarkable function of the $\mathrm{C}_{60}-\mathrm{Fe}_{2} \mathrm{O}_{3}$ composite, which generates hydroxyl radicals $(\cdot \mathrm{OH})$ via the photoelectrochemical decomposition of $\mathrm{H}_{2} \mathrm{O}_{2}$ under visible light. In order to study the synergetic effects of $\mathrm{C}_{60}$ and $\mathrm{Fe}_{2} \mathrm{O}_{3}$ in the nanocomposite, we used pure $\mathrm{Fe}_{2} \mathrm{O}_{3}$ and pure $\mathrm{C}_{60}$ with $\mathrm{H}_{2} \mathrm{O}_{2}$ to degrade $\mathrm{MB}$ solutions. In the reaction systems with pure $\mathrm{Fe}_{2} \mathrm{O}_{3}$ or pure $\mathrm{C}_{60}$ and $\mathrm{H}_{2} \mathrm{O}_{2}$ (tests g and h), very little degradation of $\mathrm{MB}$ was found after irradiation for $80 \mathrm{~min}$. In contract, test e revealed that the $\mathrm{C}_{60}-\mathrm{Fe}_{2} \mathrm{O}_{3}$ composite exhibited a good degradation effect. $\mathrm{C}_{60}-\mathrm{Fe}_{2} \mathrm{O}_{3}$ has a much better degradation effect than pure $\mathrm{Fe}_{2} \mathrm{O}_{3}$ and $\mathrm{C}_{60}$ because $\mathrm{C}_{60}$ is an energy sensitizer that improves the quantum efficiency and increases the extent of charge transfer. Thus, the synergetic effects of $\mathrm{C}_{60}$ and $\mathrm{Fe}_{2} \mathrm{O}_{3}$ can greatly improve the degradation effect.

To further confirm the catalytic activity of the as-prepared material, the degradation of $\mathrm{RhB}, \mathrm{MO}$, and phenol were also examined in the $\mathrm{C}_{60}-\mathrm{Fe}_{2} \mathrm{O}_{3} / \mathrm{H}_{2} \mathrm{O}_{2}$ /visible light system. As shown in Fig. 4(b), similar results were observed. Specifically, the discoloration of $\mathrm{RhB}$ and MO reached nearly $92 \%$ and $86.7 \%$ in 120 min, respectively. As shown in Fig. 4(c), the degradation of phenol (50 mL, $10 \mathrm{mg} / \mathrm{L}$ ) reached $96.1 \%$ in $120 \mathrm{~min}$. Therefore, the as-synthesized $\mathrm{C}_{60}-\mathrm{Fe}_{2} \mathrm{O}_{3}$ composite is a high-efficiency photocatalyst in the presence of $\mathrm{H}_{2} \mathrm{O}_{2}$ under visible light. The results show that carbon-doped photocatalytic materials have a wide range of catalytic properties and can be widely used to degrade organic contaminants, which is consistent with previous reports [37]. The mineralization degree of MB was investigated by measuring the decrease of the TOC. As shown in the inset in Fig. 4(b), the degradation and TOC removal rate of MB in 80 min reached $98.9 \%$ and $71 \%$, respectively. Therefore, the $\mathrm{C}_{60}-\mathrm{Fe}_{2} \mathrm{O}_{3} / \mathrm{H}_{2} \mathrm{O}_{2}$ /visible light system can effectively mineralize $\mathrm{MB}$ in solution.

\subsection{Effects of parameters on the degradation of $M B$}

\subsubsection{Effect of $p H$}

The $\mathrm{pH}$ usually has a significant influence on the degradation of organic matter in heterogeneous photo-Fenton reaction processes. When the $\mathrm{pH}$ is below $3, \mathrm{H}_{3} \mathrm{O}_{2}{ }^{+}$will form to enhance the stability of $\mathrm{H}_{2} \mathrm{O}_{2}$ and to scavenge $\cdot \mathrm{OH}$. Meanwhile, when the $\mathrm{pH}$ is higher than 3 , the formation of $\cdot \mathrm{OH}$ becomes slow because of the hydrolysis of $\mathrm{Fe}^{2+}$ and the precipitation of $\mathrm{FeOOH}$ from the system. Fig. 5(a) shows the relationship between the initial $\mathrm{pH}$ and the removal efficiency of MB. The discoloration process

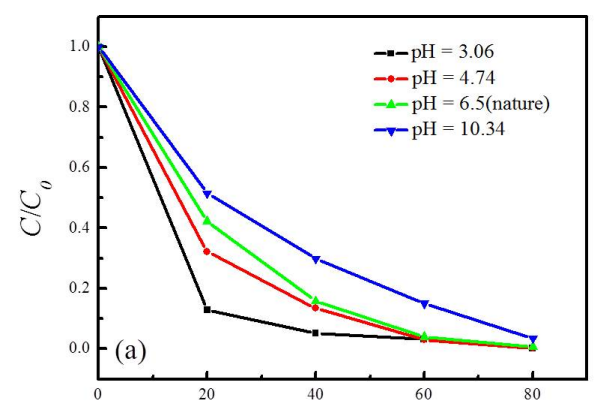

$T$ (min)

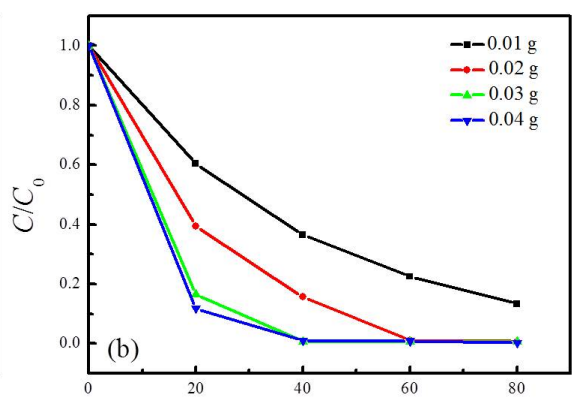

$T$ (min)

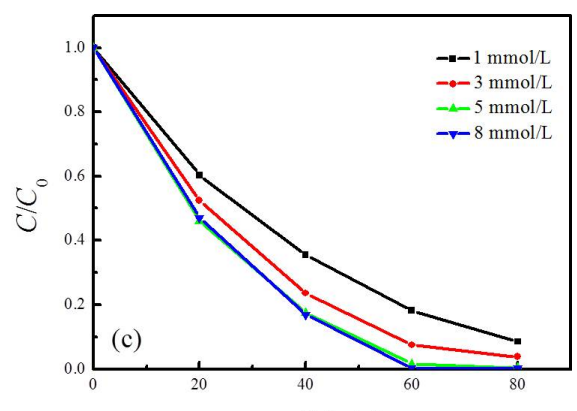

$T$ (min)

Fig. 5. Degradation of $\mathrm{MB}$ by the $\mathrm{C}_{60}-\mathrm{Fe}_{2} \mathrm{O}_{3} / \mathrm{H}_{2} \mathrm{O}_{2}$ /visible light system: (a) effect of $\mathrm{pH}$ on the degradation of $\mathrm{MB}$; (b) Effect of $\mathrm{C}_{60}-\mathrm{Fe}_{2} \mathrm{O}_{3}$ dosage on the degradation of $\mathrm{MB}$; (c) Effect of $\mathrm{H}_{2} \mathrm{O}_{2}$ dosage on the degradation of $\mathrm{MB}$. 
remained highly efficient when the $\mathrm{pH}$ was 10.34 , with a discoloration rate of $96.5 \%$. This result suggests that the $\mathrm{C}_{60}-\mathrm{Fe}_{2} \mathrm{O}_{3}$ catalyst can overcome the drawbacks of a narrow $\mathrm{pH}$ range for conventional Fenton reactions. Thus, this catalyst may also be a promising candidate for the degradation of various dyeing wastewaters.

\subsubsection{Effect of catalyst dosage}

The influence of $\mathrm{C}_{60}-\mathrm{Fe}_{2} \mathrm{O}_{3}$ dosage on the heterogeneous photo-Fenton degradation of MB is shown in Fig. 5(b). The discoloration of MB was significantly influenced by the dosage of the catalyst. The discoloration efficiency of MB increased from $86.4 \%$ to $99.3 \%$ after irradiation for 80 min when the catalyst dosage increased from 0.2 to $0.4 \mathrm{~g} / \mathrm{L}$. The reasons for this increase are twofold: (1) more catalyst could increase the adsorption of MB because additional functionalities are available on the catalyst, and (2) the increased amount of catalyst could increase the number of active sites on the catalyst surface available for the catalytic decomposition of $\mathrm{H}_{2} \mathrm{O}_{2}$, generating more $\cdot \mathrm{OH}$ [38]. Considering the cost, we chose $0.4 \mathrm{~g} / \mathrm{L}$ as the optimum catalytic dosage to conduct the following experiments.

\subsubsection{Effect of $\mathrm{H}_{2} \mathrm{O}_{2}$ dosage on $\mathrm{MB}$ degradation}

The effect of $\mathrm{H}_{2} \mathrm{O}_{2}$ dosage on the degradation of $\mathrm{MB}$ was investigated by varying the initial concentration of $\mathrm{H}_{2} \mathrm{O}_{2}$ from 1 to $8 \mathrm{mmol} / \mathrm{L}$, as shown in Fig. 5(c). When the dosage of $\mathrm{H}_{2} \mathrm{O}_{2}$ was increased from 1 to $5 \mathrm{mmol} / \mathrm{L}$, the MB removal velocity improved significantly. The increase in $\mathrm{H}_{2} \mathrm{O}_{2}$ concentration led to increased formation of $\cdot \mathrm{OH}$. However, only a slight increase was observed at higher $\mathrm{H}_{2} \mathrm{O}_{2}$ concentrations ( $8 \mathrm{mmol} / \mathrm{L}$ ). From Fig. 5 (c), we conjecture that when the initial concentration of $\mathrm{H}_{2} \mathrm{O}_{2}$ is high (such as $8 \mathrm{mmol} / \mathrm{L}$ ), it can act as a scavenger. When the initial concentration of $\mathrm{H}_{2} \mathrm{O}_{2}$ is low, it can act as radicals (intermediate) for the degradation of organic compounds. This result is observed because $\mathrm{H}_{2} \mathrm{O}_{2}$ at high concentrations acts as a scavenger of $\cdot \mathrm{OH}[39]$.

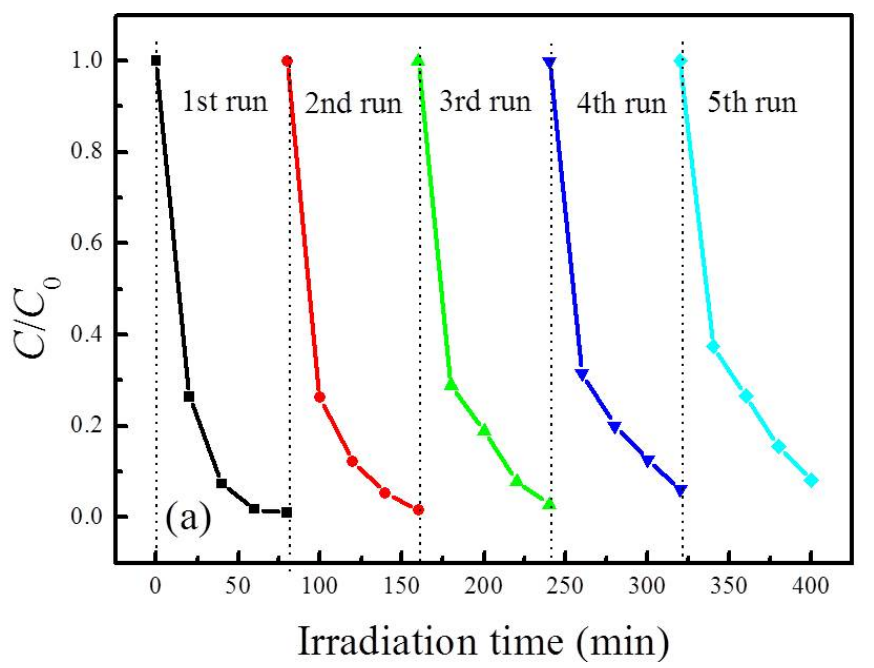

\subsection{Reusability test of $\mathrm{C}_{60}-\mathrm{Fe}_{2} \mathrm{O}_{3}$ composit}

To evaluate the reusability of the $\mathrm{C}_{60}-\mathrm{Fe}_{2} \mathrm{O}_{3}$ composite, the catalyst was collected and reused five times to conduct the photocatalytic degradation of MB. As shown in Fig. 6(a), the photodegradation rate of MB still reach over $96 \%$ after five cycles. This finding indicates that the catalyst has an excellent photocatalyst stability and a high potential application value.

\subsection{Mechanism discussion}

To exclude the influence of homogeneous Fenton reactions by iron leached into the aqueous phase, the iron concentration in the reaction solution of MB was monitored during the reaction over $80 \mathrm{~min}$. At the end of the reaction, the amount of leached iron was $0.498 \mathrm{mg} / \mathrm{L}$. This value was negligible compared with the iron content in the $\mathrm{C}_{60}-\mathrm{Fe}_{2} \mathrm{O}_{3}$ catalyst (3.25\%). The homogeneous Fenton experiment was performed using iron salts at the same concentration $(0.498 \mathrm{mg} / \mathrm{L})$ as that of leached iron. As shown in Fig 4(a)f, the degradation of MB was only $15 \%$ after 80 min. Therefore, the homogeneous Fenton reaction made only a very small contribution to MB degradation. Thus, the formation of $\cdot \mathrm{OH}$ is probably mainly attributable to the heterogeneous photo-Fenton reaction.

To confirm this assumption, we utilized the fluorescent probe terephthalic acid (TA) to assess $\cdot \mathrm{OH}$ formation. The fluorescent probe TA $(1.0 \mathrm{mmol} / \mathrm{L})$ was added into the $\mathrm{C}_{60}-\mathrm{Fe}_{2} \mathrm{O}_{3} / \mathrm{H}_{2} \mathrm{O}_{2}$ /visible light system. TA easily reacted with $\cdot \mathrm{OH}$ to form highly fluorescent 2-hydroxyterephthalic acid (HTA). As shown in Fig. 7(a), the fluorescence peak at $426 \mathrm{~nm}$ confirmed the formation of $\cdot \mathrm{OH}$ during visible irradiation, indicating that $\cdot \mathrm{OH}$ was photogenerated in the reaction system. To further confirm that $\cdot \mathrm{OH}$ plays a major role in the whole process, we also carried out active species trapping experiments to determine the main active oxidant in the photocatalytic reaction process. Isopropanol $(2.0 \mathrm{~mL})$, disodium ethylenediaminetetraacetate (EDTA-2Na) (30 mg), and nitrogen gas were

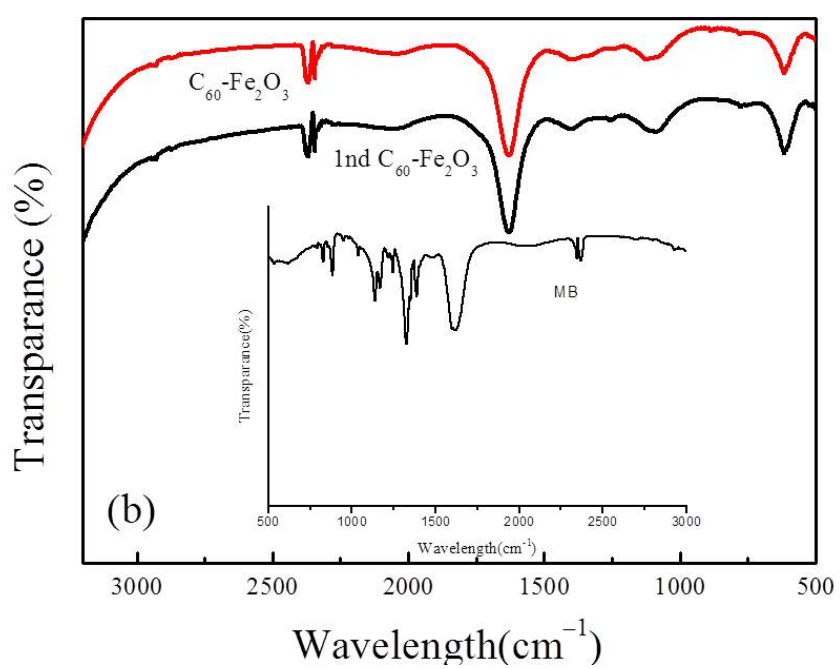

Fig. 6. (a) Reusability of $\mathrm{C}_{60}-\mathrm{Fe}_{2} \mathrm{O}_{3}$ for the degradation of MB; (b) FT-IR spectra of the as-prepared catalyst and the recycled catalyst after the first run. The inset shows the FT-IR spectrum of pure MB. 

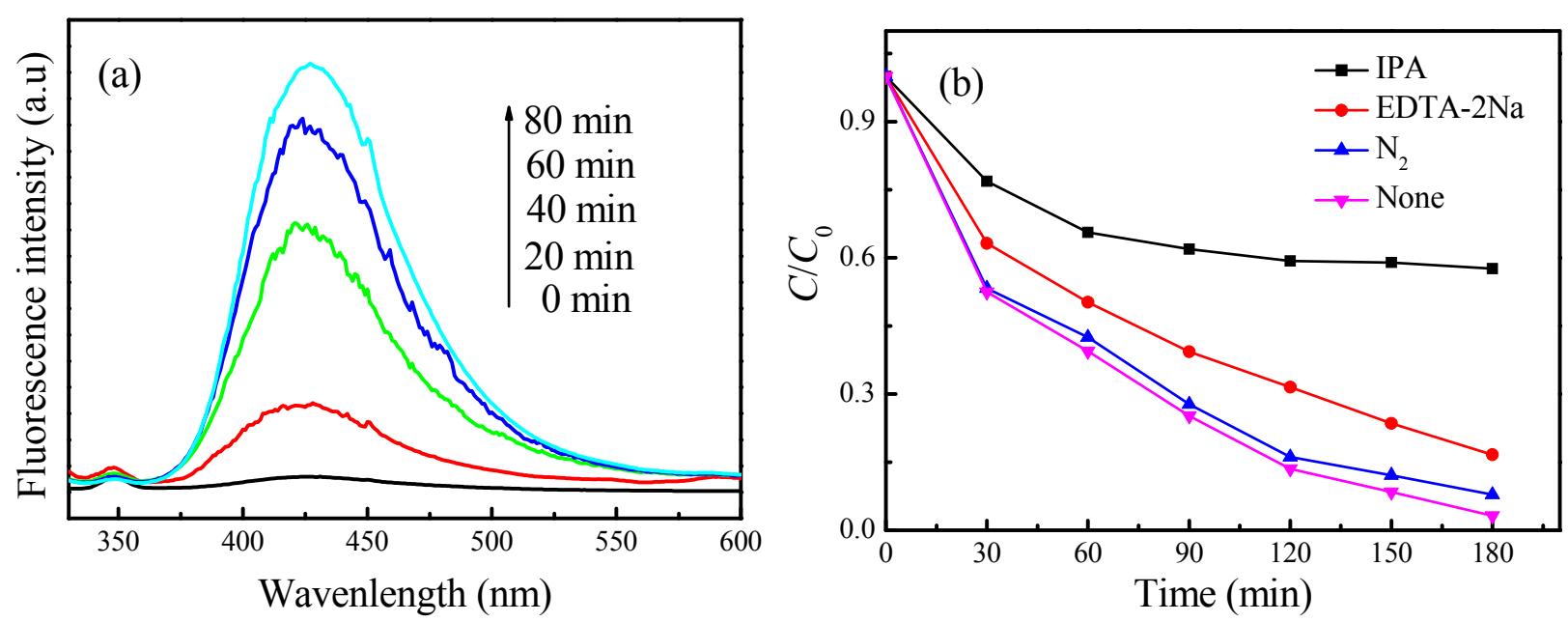

Fig. 7. (a) $\cdot \mathrm{OH}$-trapping photoluminescence spectra for the $\mathrm{C}_{60}-\mathrm{Fe}_{2} \mathrm{O}_{3} / \mathrm{H}_{2} \mathrm{O}_{2} /$ visible light system; (b) Active species trapping experiments.

introduced as reactive species scavengers for $\cdot \mathrm{OH}$, holes $(h v)$, and superoxide anion radicals $\left(\cdot \mathrm{O}_{2}^{-}\right)$, respectively. As shown in Fig. 7(b), the addition of isopropanol greatly reduced the photodegradation rate of MB, whereas the addition of EDTA-2Na and purging with nitrogen gas had relatively weak effects on the photodegradation of MB. Therefore, we can conclude that $\cdot \mathrm{OH}$ is the main oxidant in the reaction system. These findings are consistent with the results for decomposition of MB (Fig. $4(\mathrm{a}) \mathrm{e})$, which shows that $\cdot \mathrm{OH}$ is the main active species.

Based on the above results, we proposed a plausible mechanism for the $\mathrm{C}_{60}-\mathrm{Fe}_{2} \mathrm{O}_{3} / \mathrm{H}_{2} \mathrm{O}_{2}$ /visible light catalytic system, as presented in Scheme 1. Firstly, MB is adsorbed on the surface of the $\mathrm{C}_{60}-\mathrm{Fe}_{2} \mathrm{O}_{3}$ catalyst. Secondly, as a photosensitizer, when $\mathrm{C}_{60}$ is irradiated with visible light, it is excited from the ground state to a short-lived singlet excited state (ca. $1.2 \mathrm{~ns}$ ), which undergoes rapid intersystem crossing at a rate of $5.0 \times 10^{8} \mathrm{~s}^{-1}$ to a lower lying triplet state $\left({ }^{3} \mathrm{C}_{60}{ }^{*}\right)$ with a long lifetime $(>40$ $\mu \mathrm{s})$. More importantly, photoexcited fullerenes are also excellent electron acceptors capable of accepting as many as six electrons. ${ }^{3} \mathrm{C}_{60}{ }^{*}$ has a higher electron accepting ability than ground state ${ }^{1} \mathrm{C}_{60}$, and electron-donating compounds can reduce ${ }^{3} \mathrm{C}_{60}{ }^{*}$ to give the $\mathrm{C}_{60}$ radical anion $\left({ }^{3} \mathrm{C}_{60}{ }^{-}\right)$. As the potential

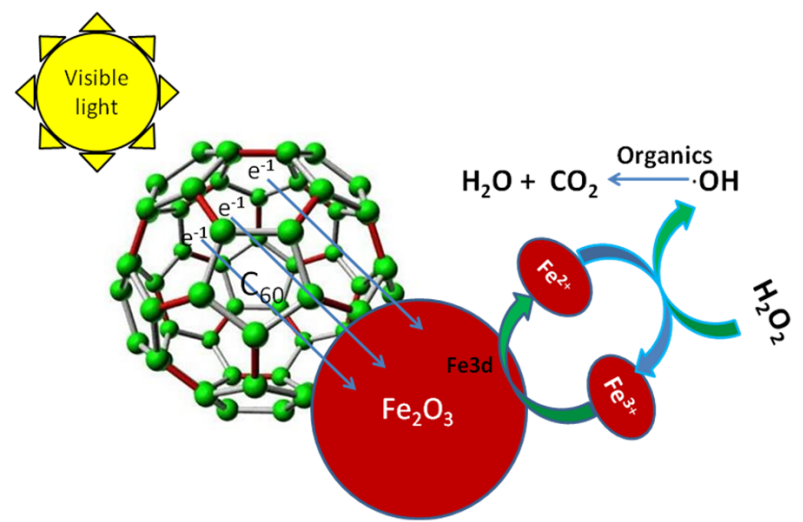

Scheme 1. Reaction mechanism of the heterogeneous $\mathrm{C}_{60}-\mathrm{Fe}_{2} \mathrm{O}_{3}$ photo-Fenton catalyst for the degradation of organics. of the conduction band of $\mathrm{Fe}_{2} \mathrm{O}_{3}$ and the potential of the transformation $\left({ }^{3} \mathrm{C}_{60}{ }^{*} /{ }^{3} \mathrm{C}_{60}{ }^{\circ-}\right)$ is equal to $-0.2 \mathrm{eV}$, electrons may be transmitted from the conduction band of $\mathrm{Fe}_{2} \mathrm{O}_{3}$ to ${ }^{3} \mathrm{C}_{60}{ }^{*}$, resulting in the formation of ${ }^{3} \mathrm{C}_{60}{ }^{\circ-}$ This radical species may react further with reactants adsorbed at the interface [40]. C60 could use its own photoabsorptive characteristics to absorb electrons from photoinduced irradiation and transfer them to the Fe $3 d$ orbital of $\mathrm{Fe}_{2} \mathrm{O}_{3}$ to generate $\mathrm{Fe}^{2+}$. Subsequently, the formed $\mathrm{Fe}^{2+}$ could react with $\mathrm{H}_{2} \mathrm{O}_{2}$ to produce $\cdot \mathrm{OH}$. Simultaneously, $\mathrm{Fe}^{2+}$ is oxidized into $\mathrm{Fe}^{3+}$ to achieve the $\mathrm{Fe}^{3+} / \mathrm{Fe}^{2+}$ cycle. Next, $\cdot \mathrm{OH}$ degrades $\mathrm{MB}$ adsorbed on the surface of the catalyst to $\mathrm{CO}_{2}$ and $\mathrm{H}_{2} \mathrm{O}$. Finally, the catalyst is restored to the original state. The deposition of $\mathrm{C}_{60}$ on the $\mathrm{Fe}_{2} \mathrm{O}_{3}$ surface is expected to improve the photocatalytic behavior. Fullerene can generate $\mathrm{e}^{-} / \mathrm{h}^{+}$pairs under visible-light irradiation. It can be proposed that $\mathrm{e}^{-}$transfer also occurs in the $\mathrm{C}_{60}-\mathrm{Fe}_{2} \mathrm{O}_{3}$ composite between fullerene and $\mathrm{Fe}_{2} \mathrm{O}_{3}$, retarding the $\mathrm{e}^{-} / \mathrm{h}^{+}$recombination and increasing the photon efficiency [41].

\section{Conclusions}

In this study, a highly efficient heterogeneous photo-Fenton $\mathrm{C}_{60}-\mathrm{Fe}_{2} \mathrm{O}_{3}$ catalyst was successfully prepared by an easy and stable impregnation method. Under the optimum conditions ( $0.02 \mathrm{~g}$ catalyst and $5 \mathrm{mmol} / \mathrm{L} \mathrm{H}_{2} \mathrm{O}_{2}$ ), $98.9 \%$ discoloration and $71 \%$ mineralization of MB (50 mg/L) were achieved within 80 min. The $\mathrm{C}_{60}-\mathrm{Fe}_{2} \mathrm{O}_{3}$ catalyst showed a high photocatalytic activity over a wide $\mathrm{pH}$ range 3.06-10.34. This catalyst was also highly effective for the degradation of MB after five reaction cycles. The results showed that iron leaching from the catalyst was negligible. The catalyst was also effective for the degradation of $\mathrm{RhB}, \mathrm{MO}$, and phenol. The $\mathrm{C}_{60}-\mathrm{Fe}_{2} \mathrm{O}_{3}$ catalyst has potential as a heterogeneous catalyst for various dyeing wastewater treatments because of its high catalytic activity, wide $\mathrm{pH}$ range, good stability, and insignificant iron leaching. We also used active species trapping experiments to reveal the main active oxidant in the photocatalytic reaction process, finding that the hydroxyl radicals play a major role in the entire process. 


\section{Graphical Abstract}

Chin. J. Catal., 2018, 39: 1051-1059 doi: 10.1016/S1872-2067(18)63067-0

Preparation of a fullerene[60]-iron oxide complex for the photo-fenton degradation of organic contaminants under visible-light irradiation

Cong-yang Zou, Ze-da Meng, Wen-chao Ji, Shou-qing Liu, Zhemin Shen *, Yuan Zhang, Ni-shan Jiang

Shanghai Jiao Tong University; Suzhou University of Science and Technology-Shihu Campus

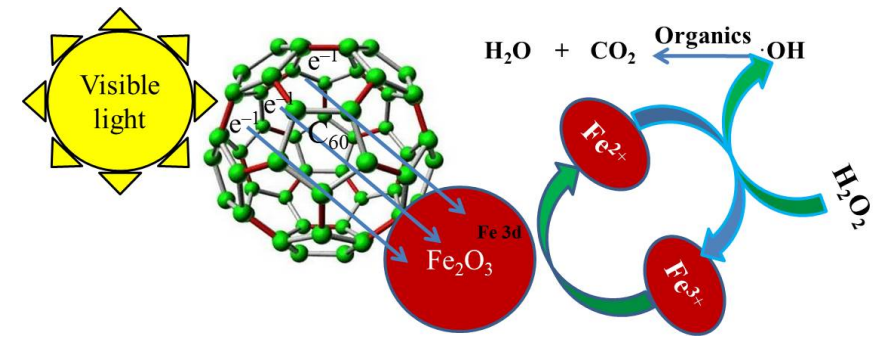

This is a highly efficient heterogeneous photo-Fenton system. The $\mathrm{C}_{60}$ on the $\mathrm{Fe}_{2} \mathrm{O}_{3}$ surface is expected to improve the photocatalytic behavior. $\cdot \mathrm{OH}$ plays a major role in the system and degrades the organic compounds to $\mathrm{CO}_{2}$ and $\mathrm{H}_{2} \mathrm{O}$.

\section{References}

[1] R. P. Schwarzenbach, B. I. Escher, K. Fenner, T. B. Hofstetter, C. A. Johnson, U. von Gunten, B. Wehrli, Science, 2006, 313, 1072-1077.

[2] D. B. Lu, Y. Zhang, S. Lin, L. Wang, C. Wang, J. Alloys. Compd., 2013, 579, 336-342.

[3] A. A. Farghali, M. Bahgat, W. M. A El Rouby, M. H. Khedr, J. Alloys. Compd., 2013, 555, 193-200.

[4] Y. Chen, N. Li, Y. Zhang, L. Zhang, J. Colloid. Interfaces Sci., 2014, 422, 9-15.

[5] F. B. Li, X. Z. Li, X. M. Li, T. X. Liu, J. Dong, J. Colloid. Interfaces Sci., 2007, 311, 481-490.

[6] W. Jiang, W. S. Zhu, H. M. Li, Y. H. Chao,S. H. Xun, Y. H. Chang, H. Liu, Z. Zhao, J. Mol. Catal. A, 2014, 382, 8-14.

[7] N. M. Mahmoodi, Environ. Monit. Assess., 2014, 186, 5595-5604.

[8] C. Singh, S. Bansal, V. Kumar, S Singhal, Ceram. Intern., 2015, 41, 3595-3604.

[9] J. Ma, L. Z. Zhang, Y. H. Wang, S. L. Lei, X. B. Luo, S. H. Chen, G. S. Zeng, J. P. Zou, S. L. Luo, C. T. Au, Chem. Eng. J., 2014, 251, 371-380.

[10] S. B. Zhu, T. G. Xu, H. B. Fu, J. Zhao, Y. Zhu, Environ. Sci. Technol., 2007, 41, 6234-6239.

[11] G. Li, B. Jiang, X. Li, Z. C. Lian, S. N. Xiao, J. Zhu, D. Q. Zhang, H. X. Li, ACS App. Mater. Interfaces, 2013, 5, 7190-7197.

[12] P. Bouras, E. Stathatos, P. Lianos, App. Catal. B, 2007, 73, 51-59.

[13] L. W. Zhang, Y. J. Wang, T. G. Xu, S. B. Zhu, Y. F. Zhu, J. Mol. Catal. A, 2010, 331, 7-14.

[14] G. Yu, J. Gao, J. C. Hummelen, F. Wudl, A. J. Heeger, Science, 1995, 1789-1791.

[15] M. Wang, Z. W. Wang, L. Wei, J. W. Li, X. S. Zhao, Chin. J. Catal., 2017, 38, 1680-1687.

[16] X. Zhao, H. J. Liu, Y. L. Shen, J. H. Qu, App. Catal. B, 2011, 106, 63-68.

[17] Z. D. Meng, L. Zhu, J. G. Choi, C. Y. Park, W. C. Oh, Nanoscale Res. Lett., 2011, 6, 459.

[18] B. Chai, X. Liao, F. K. Song, H. Zhou, Dalton Trans., 2014, 43, 982-989.

[19] M. Barroso, A. J. Cowan, S. R. Pendlebury, M. Grätzel, D. R. Klug, J. R. Durrant, J. A. Chem. Soc., 2011, 133, 14868-14871.
[20] M. A. Gondal, A. Hameed, Z. H. Yamani, A. Suwaiyan, App. Catal. A, 2004, 268(1), 159-167.

[21] O. Akhavan, Appl. Surf. Sci., 2010, 257, 1724-1728.

[22] Y. X. Deng, H. X. Huangfu, S. H. Tang, J. Li, Chin. J. Catal., 2017, 38, 1668-1679.

[23] C. Chen, J. Hu, D. Shao, J. Li, X. Wang, J. Hazard. Mater., 2009, 164, 923-928.

[24] L. H. Ai, C. Y. Zhang, Z. L. Chen, J. Hazard. Mater., 2011, 192, 1515-1524.

[25] G. Q. Xie,J. Cheng, Y. F. Li, P. X. Xi, F. J. Chen, H. Y. Liu, F. P. Hou, Y. J. Shi, L. Huang, Z. H. Xu, D. C. Bai, Z. Z. Zeng J. Mater. Chem., 2012, 22, 1033-1039.

[26] S. P. West, T. Poon, J. L. Anderson, M, A, West, C. S. Foote, J. Chem. Educ., 1997, 74, 311-312.

[27] H. Veisi, R. Masti, D. Kordestani, M. Safaei, O. Sahin, J. Mol. Catal. A, 2014, 385, 61-67.

[28] U. Holzwarth, N. Gibson, Nat. Nanotechnol., 2011, 6, 534-534.

[29] D. Patil, V. Patil, P. Patil, Sens. Actuat. B, 2011, 152, 299-306.

[30] O. Akhavan, R. Azimirad, App. Catal. A, 2009, 369, 77-82.

[31] X. Song, Y. Yan, X. Q. Li, J. Zhang, P. P. Yao, S. Z. Kang, J. Mu, Chin. J. Inorg. Chem., 2011, 27, 1047-1052.

[32] H. Orita, N. Itoh, App. Catal. A, 2004, 258, 17-23.

[33] V. Chhabra, P. Ayyub, S. Chattopadhyay, A. N. Maitra, Mater. Lett., 1996, 26, 21-26.

[34] X. Y. Yang, X. Y. Zhang, Y. F. Ma, Y. Huang, Y. Wang, Y. Chen, J. Mater. Chem., 2009, 19, 2710-2714.

[35] Y. H. Zhang, Z. R. Tang, X. Z. Fu, Y. J. Xu, ACS Nano, 2010, 4, 7303-7314

[36] J. L. Zhang, G. L. Chen, Q. Zhang, F. Kang, Y. Bo, ACS Appl. Mater. Interfaces, 2015, 7, 12760-12766.

[37] R. Rahimi, S. Zargan, A. Ghaffarinejad, A. Morsali, Environ. Prog. Sustain. Energy, 2016, 35, 642-652.

[38] M. S. Hamdy, G. Mul, App. Catal. B, 2015, 174, 413-420.

[39] A. Asghar, A. R. Abdul Aziz, W. M. A. W. Daud, J. Cleaner Prod., 2015, 87, 826-838.

[40] L. Ren, Y. Z. Li, J. T. Hou, X. J. Zhao, X. C. Pan, ACS Appl. Mater. Interfaces, 2014, 6, 1608-1615.

[41] Y. Z. Li, W. Xie, X. L. Hu, G. F. Shen, X. Zhou, Y. Xiang, X. J. Zhao, P. F. Fang, Langmuir, 2010, 26, 591-597. 


\title{
可见光辐射下富勒烯[60]-氧化铁复合催化剂的制备及光芬顿法降解 有机污染物研究
}

\author{
邹丛阳 ${ }^{\mathrm{a}, \mathrm{b}}$, 孟则达 ${ }^{\mathrm{b}}$, 纪文超 ${ }^{\mathrm{a}}$, 刘守清 ${ }^{\mathrm{b}}$, 申哲民 ${ }^{\mathrm{a}}{ }^{*}$, 张 园 ${ }^{\mathrm{b}}$, 蒋妮姗 ${ }^{\mathrm{b}}$ \\ a 上海交通大学环境科学与工程学院, 上海 200240 \\ b苏州科技大学环境科学与工程学院石湖校区, 江苏苏州 215009
}

\begin{abstract}
摘要: 采用简单的可升级的化学浸渍法, 将 $\mathrm{Fe}_{2} \mathrm{O}_{3}$ 掺杂到富勒烯 $[60]\left(\mathrm{C}_{60}\right)$ 上, 制得 $\mathrm{C}_{60}-\mathrm{Fe}_{2} \mathrm{O}_{3}$ 纳米复合材料. 采用了粉末 $\mathrm{X}$ 射线衍射、X 射线光电子能谱 (XPS)、扫描电镜、高分辨透射电镜、紫外-可见吸收光谱、拉曼光谱和傅里叶变换红外光 谱, 对其进行了表征. 结果发现, XPS 数据中, $\mathrm{Fe} 2 p_{3 / 2}$ 和 $\mathrm{Fe} 2 p_{1 / 2}$ 的 XPS 特征峰分别位于结合能 710.9 和 $724.1 \mathrm{eV}$ 处, 对应 $\mathrm{Fe}_{2} \mathrm{O}_{3}$ 的 $\mathrm{Fe}^{3+}$. 富勒烯颗粒均匀分散在 $\mathrm{Fe}_{2} \mathrm{O}_{3}$ 纳米颗粒表面, $\mathrm{Fe}_{2} \mathrm{O}_{3}$ 纳米颗粒的平均尺寸大约为 20-30 nm; $\mathrm{Fe}_{2} \mathrm{O}_{3}$ 对于可见 光只有微弱的吸收, 而制备出的 $\mathrm{C}_{60}-\mathrm{Fe}_{2} \mathrm{O}_{3}$ 纳米复合材料对于可见光有较强的吸收响应.

本文将 $\mathrm{C}_{60}-\mathrm{Fe}_{2} \mathrm{O}_{3}$ 纳米复合光催化材料用于光催化降解 $50 \mathrm{~mL}, 20 \mathrm{mg} / \mathrm{lMB}$ 和 $50 \mathrm{~mL}, 10 \mathrm{mg} / \mathrm{L}$ 苯酚实验. 结果发现, 在 双氧水存在下和可见光 $(>420 \mathrm{~nm})$ 辐射条件下, $\mathrm{C}_{60}-\mathrm{Fe}_{2} \mathrm{O}_{3}$ 对上述有机污染物均有较好的降解效果. 通过测定上述有机物的 削减程度, 评估了 $\mathrm{C}_{60}-\mathrm{Fe}_{2} \mathrm{O}_{3}$ 催化剂的光催化活性, 通过改变实验条件, 得到可见光 $/ \mathrm{C}_{60}-\mathrm{Fe}_{2} \mathrm{O}_{3}$ /双氧水体系的最佳光催化降 解条件: 在 $\mathrm{pH}$ 值为 3.06 10.34 的范围内, 投加 $0.02 \mathrm{~g}$ 催化剂, $5 \mathrm{~mol} / \mathrm{L}$ 双氧水. 结果表明, 在最佳条件下, 亚甲基蓝在 80 $\min$ 内脱色率能达到 $98.9 \%$, 矿化率能达到 $71 \%$. 浸出实验的结果表明, $\mathrm{C}_{60}-\mathrm{Fe}_{2} \mathrm{O}_{3}$ 复合光催化剂中的铁浸出量可以忽略不 计. 经过 5 次循环使用后, $\mathrm{C}_{60}-\mathrm{Fe}_{2} \mathrm{O}_{3}$ 复合光催化剂仍具有较高的光催化活性. 为了进一步验证 $\mathrm{C}_{60}-\mathrm{Fe}_{2} \mathrm{O}_{3}$ 复合光催化剂的 应用广泛性, 本文在可见光 $/ \mathrm{C}_{60}-\mathrm{Fe}_{2} \mathrm{O}_{3}$ 双氧水体系下, 开展了降解 $\mathrm{RhB}, \mathrm{MO}$ 和苯酚的试验, 结果发现, 该催化剂它们也具有 高的降解效果. 机理研究发现, $\mathrm{C}_{60}-\mathrm{Fe}_{2} \mathrm{O}_{3}$ 复合光催化剂的高效催化能力可归因于 $\mathrm{C}_{60}$ 和 $\mathrm{Fe}_{2} \mathrm{O}_{3}$ 的协同效应: 在可见光辐射 下, 由于 $\mathrm{C}_{60}$ 具有独特的光敏性特征, 能够接收电子并把它们转移到 $\mathrm{Fe}_{2} \mathrm{O}_{3}$ 的 $\mathrm{Fe} 3 d$ 轨道, 并通过一系列反应, 达到 $\mathrm{Fe}^{3+} / \mathrm{Fe}^{2+}$ 循环平衡. 利用活性组分捕集实验, 对光催化反应过程中的主要活性氧化剂进行了区分. 结果表明, 羟基自由基在整个过 程中发挥了最主要的作用.
\end{abstract}

关键词: $\mathrm{C}_{60}-\mathrm{Fe}_{2} \mathrm{O}_{3}$; 多相光催化; 光-芬顿; 可见光; 活性成份的捕获

收稿日期: 2018-01-08. 接受日期: 2018-03-21. 出版日期: 2018-06-05.

*通讯联系人. 电话: (021)54745262; 传真: (021)54742863; 电子信箱: shenzhemin@sina.com.cn

基金来源：国家自然科学基金 $(21347006,21576175,51478285,51403148)$; 苏州科技大学江苏省环境科学与工程重点实验室开放

课题 (zd131205); 水处理技术与材料协同创新中心, 苏州分离净化材料和技术重点实验室 (SZS201512).

本文的电子版全文由Elsevier出版社在ScienceDirect上出版(http://www.sciencedirect.com/science/journal/18722067). 